\title{
Physico-chemical properties of mixed jam from pineapple and sweet gourd
}

\section{J. Ferdous and Md. Abdul Alim}

Department of Food Technology and Rural Industries, Bangladesh Agricultural University, Mymensingh-2202, Bangladesh

\begin{tabular}{|c|c|}
\hline ARTICLE INFO & Abstract \\
\hline $\begin{array}{l}\text { Article history: } \\
\text { Received: 08 May } 2018 \\
\text { Accepted: } 16 \text { July } 2018\end{array}$ & \multirow{3}{*}{$\begin{array}{l}\text { This study investigated the preparation of mixed jam from sweet gourd and pineapple. The proximate } \\
\text { compositions of sweet gourd pulp were: moisture content } 90.3 \% \text {, ash } 0.33 \% \text {, sugar } 3.24 \% \text { and ascorbic } \\
\text { acid } 2.97 \mathrm{mg} / 100 \mathrm{~g} \text {. Pineapple pulp contained } 74.6 \% \text { moisture, } 0.3 \% \text { ash, } 9.95 \% \text { sugar and } 78.79 \mathrm{mg} / 100 \\
\text { gascorbic acid. The keeping quality and shelf life of the prepared mixed jam were studied. For the case of } \\
\text { mixed jam, the highest sugar content }(62.54 \% \text { ) was in sample with } 60 \% \text { pineapple and } 40 \% \text { sweet gourd. } \\
\text { Organoleptic test showed that overall acceptability of } 60 \% \text { pineapple }+40 \% \text { sweet gourds was better than } \\
\text { that of other mixed jam. The highest score (8.0) was found from the sample with } 60 \% \text { pineapple }+40 \% \\
\text { sweet gourd, and the lowest score }(6.0) \text { was from the sample with } 50 \% \text { pineapple }+50 \% \text { sweet gourd. } \\
\text { During storage period, TSS, reducing sugar, non-reducing sugar and pH decreased for all cases. Fading of } \\
\text { color was observed at } 90 \text { days of storage for some samples. }\end{array}$} \\
\hline $\begin{array}{l}\text { Keywords: } \\
\text { Jam, Sweet Gourd, Pineapple, } \\
\text { Ascorbic acid }\end{array}$ & \\
\hline $\begin{array}{l}\text { nce: } \\
\lim \end{array}$ & \\
\hline
\end{tabular}

\section{Introduction}

Sweet gourd (Cucurbita maxima) belongs to the family Cucurbitaceae and is grown primarily as a vegetable or ornamental plant. The annual production of sweet gourd in Bangladesh is 1989865 metric tons (BBS, 2012). Sweet gourd is one of the most popular field crops and cultivated around the world. It is one of the most important vegetables grown in Bangladesh. Both immature and mature sweet gourds are used as a vital ingredient for several culinary preparations in Bangladesh. Sweet gourd is very versatile in its usages for cooking. Most parts of the sweet gourd are edible, including the fleshy orange shell, the seeds, the leaves, and even the flowers. The nutritive values of sweet gourd per $100 \mathrm{~g}$ edible portion were found to be carbohydrate $4.5 \mathrm{~g}$, protein $1.4 \mathrm{~g}$, fat $0.5 \mathrm{~g}$, energy $30 \mathrm{cal}$ and vitamin C $26.0 \mathrm{mg}$ (Sharfuddin and Siddique, 1985).

Pineapple (Ananascomosus) is a delicious fruit in Bangladesh. It is very much favored for its attractive color and flavor. The world production of pineapple shows a steady increase over the years; much of the increase is due to the expansion of pineapple processing industry in the developing countries of the East Africa and Latin America. Statistical data shows that about 37037acreage land is under pineapple cultivation in Bangladesh with an annual production of 218582 metric tons (BBS, 2012). Pineapple is the source of vitamin A, B, C; calcium; protein; carbohydrate; iron; carotene, etc. It also contains the protein digesting enzyme, brome in (Collins, 1968). The composition of pineapple are: moisture content $75 \%$, reducing sugar $3.06 \%$, nonreducing sugar $6.88 \%$, total sugar $19.94 \%$, ascorbic acid $8.76 \mathrm{mg} / 100 \mathrm{~g}$, ash $0.56 \%$, acidity $0.64 \%$, pH2.57 and T.S.S. 13\% (Kurt et al., 2007).
Fruits and vegetables are important sources of energy and nutrients for human beings with availability only during specific season. People of all age groups like them. Due to high water content, they are perishable. Preparation of juice, jam, jelly, marmalade, etc. increases the shelf life of fruits allowing access to consumers all year round (Pavlova et al., 2013). Jam is a product made with whole fruit, cut into pieces or crushed. The fruit is heated with water and sugar to activate the pectin in the fruit (Wikipedia, 2012). Generally, jam is produced by taking mashed or chopped fruit or vegetable pulp and boiling it with sugar and water. The proportion of sugar and fruit varies according to the type of fruit and its ripeness, but a rough starting point is equal weights of each. When the mixture reaches a temperature of $104^{\circ} \mathrm{C}\left(219^{\circ} \mathrm{F}\right)$, the acid and pectin in the fruit react with the sugar, and the jam will set on cooling (Ejiofor and Owuno, 2013). This research work was undertaken for processing and quality evaluation of mixed jam from sweet gourd and pineapple. The objectives of this study were: (i) to analyze the composition of sweet gourd and pineapple, (ii) to prepare mixed jam and analyze its composition, (iii) to evaluate sensory attribute of the jam, and (iv) to observe shelf life of the jam during storage.

\section{Materials and Methods}

The experiment was conducted in the laboratories of the Department of Food Technology and Rural Industries, under the Faculty of Agricultural Engineering and Technology, Bangladesh Agricultural University, Mymensingh-2202, during October 2014 to October 2015.

\section{Raw materials}

Pineapple used in the study was collected from Madhupur market, Tangail. Only fresh and mature fruits were used in this study. Fresh and ripe sweet gourds 
were collected from the local market used in the study. Sugar and other ingredients were used from the laboratory stock.

\section{Preparation of sweet gourd pulp}

The fresh sweet gourds of uniform color and not over ripe were sorted and washed with clean water. The inedible portion and the seeds were removed and cut into pieces using a clean table knife. The pieces were boiled, blended and cooled. After sieving the blended sweet gourd, fresh sweet gourd pulp was obtained.

\section{Preparation of pineapple pulp}

The fresh pineapples, firm and not over ripe, were sorted and washed with clean water. Then these were peeled and cut into pieces using a clean table knife and washed. The pieces were boiled, blended and cooled. After sieving the blended pineapple, required pulp was obtained.

\section{Preparation of jam from sweet gourd and pineapple} At first, we mixed sweet gourd pulp and pineapple pulp at different ratio for five different samples. Sample $\mathrm{S}_{1}$ ( $50 \%$ pineapple $+50 \%$ sweet gourd), $S_{2}$ (40\% pineapple $+60 \%$ sweet gourd), $S_{3}$ (30\% pineapple $+70 \%$ sweet gourd), sample $\mathrm{S}_{4}(60 \%$ pineapple $+40 \%$ sweet gourd), sample $\mathrm{S}_{5}(70 \%$ pineapple $+30 \%$ sweet gourd $)$ and control (pineapple only) were prepared. After mixing sweet gourd and pineapple pulps, sugar and pectin were added. The mixers were boiled for getting TSS up to $67 \%$. After that, citric acid was added. Finally, the prepared jam was bottled, capped, labeled and lastly stored for further studies.

\section{Chemical analysis}

Moisture content determination: Moisture content was determined by adopting the method by Ranganna (2003). At first, the weight of 3 empty dry crucibles was taken and $5 \mathrm{~g}$ of each sample was taken in each dried crucible. The crucibles with the samples were dried in an air oven at $105^{\circ} \mathrm{C}$ for $24 \mathrm{~h}$ or more to get constant weight. The crucibles were cooled in desiccators and weighed soon after reaching room temperature. The losses in weight were taken as the moisture loss of the samples and the percent of moisture in the samples were calculated as:

$$
\% \text { Moisture }=\frac{\text { Loss in weight }}{\text { Weight of sample }} \times 100
$$

Ash content: AOAC (2005) method was used to determine the total ash content. Two-gram of each sample was taken in a dry, clean porcelain dishes and weighed. Hot air oven method was applied to remove the moisture. The sample was burned in a gas burner and transferred into the muffle furnace. It was heated for 4 to $6 \mathrm{~h}$ at $550^{\circ} \mathrm{C}$ and ignited until light gray ash resulted (or to constant weight). The sample was cooled in a desiccator and weighed. The ash content is expressed as:

$$
\% \text { ash }=\frac{\text { Weight of residue }}{\text { Weight of sample }} \times 100
$$

\section{Vitamin-C content (Ascorbic acid)}

Ascorbic acid was determined by the method reported by Ranganna (2003).

\section{Reagents}

Meta phosphoric acid $\left(\mathrm{HPO}_{3}\right)$ : This was prepared by dissolving the sticks or pellets of $\mathrm{HPO}_{3}$ in glass-distilled water.

Standard ascorbic acid: Accurately 100mg of L ascorbic acid was weighed and the volume was made up to $100 \mathrm{ml}$ with $3 \% \mathrm{HPO}_{3}$. Ten milliliters were diluted to $100 \mathrm{ml}$ with $3 \% \mathrm{HPO}_{3}$.

Dye solution: Fifty (50) milligram sodium salt was dissolved in 2, 6-dichlorophenol indophenol in approximately $150 \mathrm{ml}$ of hot glass distilled water containing $42 \mathrm{mg}$ of sodium bicarbonate. It was cooled and diluted with glass-distilled water to $200 \mathrm{ml}$. It was stored in refrigerator and standardized every day.

The dye 2, 6-dichlorophenol indophenol was blue in alkaline solution and was reduced to light red color by an ascorbic acid at $\mathrm{pH}$ range of 1.0-3.5.

\section{Standardization of dye}

Five milliliters of standard ascorbic acid solution and $5 \mathrm{ml}$ of $\mathrm{HPO}_{3}$ were taken. A micro burette was filled with dye and titrated with dye solution to a pink colour, which should persist for 15 seconds. The dye factor was determined (i.e., $\mathrm{mg}$ of ascorbic acid per $\mathrm{ml}$ of the dye) using the following formula:

Dye factor $=\frac{0.5}{\text { Titre }}$

\section{Preparation of samples}

Five (5) grams of the pineapple and sweet gourd sample were taken, and made up to $100 \mathrm{ml}$ with $3 \% \mathrm{HPO}_{3}$ and then filtered.

\section{Titration}

Ten (10) milliliters of the aliquot was taken in a $250 \mathrm{ml}$ conical flask. One (1.0) $\mathrm{ml}$ of $40 \%$ formaldehyde and $0.1 \mathrm{ml}$ of $\mathrm{HCl}$ were added to it and kept for 10 minutes. This was titrated with standard dye to a light pink color (end point), which persisted for 15 seconds.

Vitamin-C was estimated as:

Milligrams of vitamin-C per $100 \mathrm{~g}$ sample $=$

$$
\frac{\mathrm{T} \times \mathrm{D} \times \mathrm{V}_{1}}{\mathrm{~V}_{2} \times \mathrm{W}} \times 100
$$

where $T=$ Titer; $D=$ Dye factor; $\mathrm{V}_{1}=$ Volume of the sample; $\mathrm{V}_{2}=$ Aliquot of extract taken for estimation; and $\mathrm{W}=$ Weight of sample taken for estimation.

\section{Total soluble solid (TSS)}

Total soluble solid (TSS) was determined by using Abbe Refract meter (Model no. 8987 Pujikuki Ltd. Tokyo, 
Japan). Two drops of prepared sample was taken and placed on the prism of a rerfactometer. Percent TSS was obtained from direct reading of the refract meter.

\section{pH}

The $\mathrm{pH}$ of the sample was measured by using PERKINFLMER Merion- $\mathrm{V}$ pH meter at ambient temperature. The $\mathrm{pH}$ meter was first standardized using buffer of $\mathrm{pH} 7$. Then, for determining the $\mathrm{pH}$ of samples, a buffer of $\mathrm{pH} 4$ was sufficed. Again the $\mathrm{pH}$ meter was standardized using this buffer and checked $\mathrm{pH}$ of the sample from direct reading of the pHmeter.

\section{Titrable Acidity}

Titrable Acidity was determined using AOAC (2005) method. Five grams of sample was blended and homogenized in a blender with distilled water. Then volume was made to $100 \mathrm{ml}$ in a measuring cylinder and filtered. Ten milliliters of filtered liquid was titrated using phenolphthalein as an indicator against $0.1 \mathrm{NaOH}$. The titrable acidity was calculated from the following formula:

$\%$ Titrable acidity $=\frac{\mathrm{T} \times \mathrm{N} \times \mathrm{V}_{1} \times \mathrm{E}}{\mathrm{V}_{2} \times \mathrm{W} \times 1000} \times 100$

where $\mathrm{T}=$ Titre; $\mathrm{N}=$ Normality of $\mathrm{NaOH} ; \mathrm{V}_{1}=$ Volume of the sample; $\mathrm{E}=$ Equivalent weight of acid; $\mathrm{V}_{2}=$ Volume of sample taken for estimation; and $\mathrm{W}=$ Weight of sample.

\section{Total sugar}

Sugar content was estimated by determining the volume of unknown sugar solution of sweet gourd sample required for complete reduction of standard Fehling's solution. Sugar content was determined following the procedure of Ranganna (2012).

\section{Reducing sugar}

The reagents used for the estimation of reducing, nonreducing and total sugar were: Fehling's solution (A), Fehling's solution (B), Methylene blue indicator, 45\% Neutral lead acetate solution, and 22\% Potassium oxalate solution.

\section{Standardization of Fehling's solution}

Ten milliliters of both Fehling's solution A and Fehling's solution B were mixed together in a beaker. Ten milliliters of mixed solution was pipetted into a $250 \mathrm{ml}$ conical flask and $25 \mathrm{ml}$ distilled water was added to it. Standard sugar solution was taken in a burette. The conical flask containing mixed solution was heated on a hot plate. When the solution began to boil, three drops of methylene blue indicator solution was added to it. Mixed solution was titrated by standard sugar solution. The end point was indicated by decolorization of the indicator. Fehling's factor was calculated by using the following formula:

Fehling's factor $=\frac{\text { Titre } \times 2.5}{1000}$

\section{Preparation of the sample}

Ten grams of filtered juice and $100 \mathrm{ml}$ of distilled water were mixed in homogenizer and transferred to $250 \mathrm{ml}$ volumetric flask. It was neutralized with $\mathrm{O} .1 \mathrm{~N} \mathrm{NaOH}$ and $2 \mathrm{ml}$ lead acetate solution was added to it, and kept for 10 minutes. Five (5) ml potassium oxalate solution was addedand the volume was made at $250 \mathrm{ml}$. Then it was filtered to prepare the sample.

\section{Titration for reducing sugar}

Ranganna (2012) stated the methods of reducing sugar determination. Ten milliliters of mixed Fehling's solution was taken in a conical flask and $25 \mathrm{ml}$ of distilled water was added to it. Purified juice was taken in a burette. Conical flask containing mixed Fehling's solution was added to the flask when boiling started and titrated with solution taken in the burette at the same time. The end point was indicated by decolorization of indicator. Percent reducing sugar was calculated by using the following formula:

$$
\% \text { reducing sugar }=\frac{\mathrm{I} \times \mathrm{D} \times 100}{\mathrm{~T} \times \mathrm{W} \times 1000}
$$

where I = mg of invert sugar required to reduce known volume of Fehling's solution; $\mathrm{D}=$ Dilution factor; $\mathrm{T}=$ Titration; and $\mathrm{W}=$ Weight of sample.

\section{Non-reducing sugar}

Following Ranganna (2012), $50 \mathrm{ml}$ purified solution was taken into a conical flask. Fifty milliliters of distilled water and $5 \mathrm{~g}$ of citric acid were added to it. The conical flask was heated for 10 minutes for insertion of sucrose and cooled. The sample was then neutralized by $0.1 \mathrm{~N}$ $\mathrm{NaOH}$ solution using phenolphthalein indicator. The volume was made up to $100 \mathrm{ml}$ with distilled water. The mixed Fehling's solution was titrated using similar procedure followed as in the case of reducing sugar. The percent invert sugar was then calculated by the similar procedure as the case of reducing sugar:

$\%$ Non-reducing sugar $=\%$ Invert sugar $-\%$ Reducing sugar.

\section{Estimation of total sugar}

Total sugar was calculated as:

$\%$ Total sugar $=\%$ Reducing sugar $+\%$ Non-reducing sugar

\section{Sensory evaluation}

The consumer's acceptability of developed products was evaluated by a testing panel. The panelists were the students, teachers and employees of the Department of Food Technology and Rural Industries, Bangladesh Agricultural University, Mymensingh. The panelists (10) were asked to assign appropriate score to each product tested on a 1 to 9 point hedonic scale (Singh, 2002) for characteristics of colour, flavour, texture and overall acceptability of four samples of mixed jam. 
The scale is arranged as: $9=$ like extremely, $8=$ like very much, $7=$ like moderately, 6 = like slightly, $5=$ neither like nor dislike, $4=$ dislike slightly, $3=$ dislike moderately, $2=$ dislike very much, and $1=$ dislike extremely. The results were evaluated by analysis of variance and Duncan's New Multiple Range Test procedures of the Statistical Analysis System (SAS, 1985).

\section{Storage studies}

Processed mixed jams were stored into arefregerator. Different parameters for changing of mixed jams were observed at a regular interval of time. The acidity, sugar content, TSS, colour and flavour were observed initially at an interval of 15 days for three months.

\section{Results and Discussion}

Composition of fresh sweet gourd and fresh pineapple

The pineapple and sweet gourd were analyzed for moisture, ash, acidity, ascorbic acid and total sugar. The results are given in Table 1. The compositions of sweet gourd were: $90.3 \%$ moisture content, $0.33 \%$ ash content, $2.97 \mathrm{mg} / 100 \mathrm{~g}$ ascorbic acid,3.24\% sugar, and $0.013 \%$ acidity. The results showed a slight variation with the results of some other workers. Gopalan et al. (2001) reported that fresh sweet gourd contained 92.6\% moisture, which is very close to this study. The difference may be attributed to varietals differences and differences in climatic conditions. The variation also may be due to differences in identifying stage of maturity.

The moisture, total sugar, ascorbic acid, ash and acidity of pineapple were $84.6 \%, 9.95 \%, 78.79 \mathrm{mg} / 100 \mathrm{~g}, 0.30 \%$ and $0.67 \%$, respectively. The results showed a slight variation with the results of some other researchers. Rahman (2007) reported that fresh pineapple contained moisture content $86.56 \%$,ash content $0.361 \%$,ascorbic acid (vitamin C) $8.22 \mathrm{mg} / 100$ g,acidity $0.79 \%$, and total sugar $10.41 \%$. The differences observed in these compositions may be due to varietal differences, seasonal and seasonal effects, agro-ecological condition, fertilizer use, methods of analysis, etc.

\section{Chemical composition of mixed jam}

Moisture contents of $S_{1}, S_{2}, S_{3}, S_{4}$ and $S_{5}$ mixed jam sample were $33,31,35,37$ and $34 \%$, respectively. The highest moisture content was $37 \%$ for sample $\mathrm{S}_{4}$ and the lowest moisture content was $31 \%$ for $S_{2}$ (Table 2). Ash content of mixed jams varied from 0.208 to $0.314 \%$. The $\mathrm{pH}$ was studied to ensure physico-chemical changes during preparation of jam. The $\mathrm{pH}$ of $\mathrm{S}_{1}, \mathrm{~S}_{2}, \mathrm{~S}_{3}, \mathrm{~S}_{4}$ and $\mathrm{S}_{5}$ of mixed jam samples were 3.39, 3.33, 3.25, 3.34 and $3.43 \%$, respectively. The component, which affects the product's taste is the sugar content, which was higher in sample $\mathrm{S}_{4}(62.54 \%)$. The calorie value of jam increased with higher sugar content.
Table 1. Compositions of fresh sweet gourd and pineapple

\begin{tabular}{lcc}
\hline \multicolumn{1}{c}{ Composition } & Sweet gourd & Pineapple \\
\hline Moisture content (\%) & 90.3 & 84.6 \\
Sugar (\%) & 3.24 & 9.95 \\
Ascorbic acid (mg/100) & 2.97 & 78.79 \\
Ash (\%) & 0.33 & 0.30 \\
Acidity (\%) & 0.013 & 0.67 \\
\hline
\end{tabular}

Table 2. Composition of sweet gourd and pineapple mixed jams

\begin{tabular}{cccccc}
\hline Sample & $\begin{array}{c}\text { Moisture } \\
\text { content (\%) }\end{array}$ & Ash (\%) & TSS (\%) & $\mathrm{P}^{\mathrm{H}}$ & $\begin{array}{c}\text { Total } \\
\text { sugar (\%) }\end{array}$ \\
\hline $\mathrm{S}_{1}$ & 33 & 0.234 & 67 & 3.39 & 57.86 \\
$\mathrm{~S}_{2}$ & 31 & 0.254 & 67 & 3.33 & 60.45 \\
$\mathrm{~S}_{3}$ & 35 & 0.208 & 67 & 3.25 & 56.78 \\
$\mathrm{~S}_{4}$ & 37 & 0.314 & 67 & 3.34 & 62.54 \\
$\mathrm{~S}_{5}$ & 34 & 0.301 & 67 & 3.43 & 55.53 \\
$* \mathrm{~S}_{0}$ & 32 & 0.245 & 67 & 4.21 & 59.25 \\
\hline
\end{tabular}

$* \mathrm{~S}_{\mathrm{o}}=$ Control only pineapple; $\mathrm{S}_{1}=50 \%$ pineapple $+50 \%$ sweet gourd; $S_{2}=40 \%$ pineapple $+60 \%$ sweet gourd; $S_{3}=30 \%$ pineapple $+70 \%$ sweet gourd; $S_{4}=60 \%$ pineapple $+40 \%$ sweet gourd; $S_{5}=70 \%$ pineapple $+30 \%$ sweet gourd.

\section{Sensory evaluation of mixed jam}

The orders of preferences for color, texture, taste, overall acceptability of different sample of mixed jam were determined by Duncan's New Multiple Range Test (DMRT) and results are given in Table 3. Mixed jam samples were statistically analyzed for average score of variance of color, flavor, texture and overall acceptability $(\mathrm{P}<0.5)$. It shows that control sample $\left(\mathrm{S}_{0}\right)$ secured the highest score (9.0) followed by the sample $S_{4}$ (8.4) and $S_{3}$ (7.3) for color. The sample $S_{1}$ secured the lowest score (6.4) among the samples. The sample $S_{2}$ and $S_{5}$ were equally acceptable for color. In case of texture, the highest score was secured by $\mathrm{S}_{4}(8.0)$ and the lowest score was secured by $\mathrm{S}_{1}$ (7.0). In case of flavor preference, results show that there was significant difference among the samples. However, the highest score (8.0) for flavor was obtained from control sample. The lowest score (5.8) recorded from sample $S_{1}$. For overall acceptability, sample $\mathrm{S}_{4}$ secured the highest score (8.0). The lowest score (6.0) was obtained for sample $\mathrm{S}_{1}$.

Table 3. Duncan's New Multiple Range Test (DMRT) for color, Texture, taste and overall acceptability of mixed jams

\begin{tabular}{lcccc}
\hline Sample & \multicolumn{4}{c}{ Sensory Attributes } \\
\cline { 2 - 5 } & Color & Flavor & Texture & $\begin{array}{c}\text { Overall } \\
\text { acceptability }\end{array}$ \\
\hline $\mathrm{S}_{1}$ & $6.4^{\mathrm{d}}$ & $5.8^{\mathrm{d}}$ & $7.0^{\mathrm{c}}$ & $6.0^{\mathrm{d}}$ \\
$\mathrm{S}_{2}$ & $7.1^{\mathrm{c}}$ & $6.4^{\mathrm{c}}$ & $7.3^{\mathrm{b}}$ & $6.8^{\mathrm{c}}$ \\
$\mathrm{S}_{3}$ & $7.3^{\mathrm{c}}$ & $7.2^{\mathrm{b}}$ & $7.8^{\mathrm{a}}$ & $7.0^{\mathrm{c}}$ \\
$\mathrm{S}_{4}$ & $8.4^{\mathrm{b}}$ & $7.8^{\mathrm{a}}$ & $8.0^{\mathrm{a}}$ & $8.0^{\mathrm{a}}$ \\
$\mathrm{S}_{5}$ & $7.1^{\mathrm{c}}$ & $7.7^{\mathrm{a}}$ & $7.9^{\mathrm{a}}$ & $7.5^{\mathrm{b}}$ \\
$* \mathrm{~S}_{\mathrm{o}}$ & $9.0^{\mathrm{a}}$ & $8.0^{\mathrm{a}}$ & $8.0^{\mathrm{a}}$ & $8.0^{\mathrm{a}}$ \\
$\mathrm{LSD}$ & 0.3725 & 0.35 & 0.2279 & 0.2483 \\
\hline
\end{tabular}

* $\mathrm{S}_{\mathrm{o}}=$ Control only pineapple; $\mathrm{S}_{1}=50 \%$ pineapple $+50 \%$ sweet gourd; $S_{2}=40 \%$ pineapple $+60 \%$ sweet gourd; $S_{3}=30 \%$ 
pineapple $+70 \%$ sweet gourd; $S_{4}=60 \%$ pineapple $+40 \%$ sweet gourd; $S_{5}=70 \%$ pineapple $+30 \%$ sweet gourd.

The effect of storage time on chemical composition of mixed jam

The effects of storage period on chemical compositions of prepared jam were analyzed and observed initially at an interval of 15 days for three months. The results are presented in Table 4. During the storage time, TSS decreased slightly because of improper sealing or premature setting. Total sugar content of mixed jam decreased slowly with the increase in storage period due to evaporation of water.

The effect of storage time on color and flavor of mixed jam

The effects of storage on color and flavor were observed and results are given in Table 5 and Table 6 . The color of the mixed jam for all samples remained unchanged for 30 days. But, at 45 days, color of sample $S_{1}$ and $S_{2}$ changed to slight whitish. The color of sample $\mathrm{S}_{4}$ was unchanged for 75 days. Variations of color in different formulations were due to the varied content of mixed pulp and hence the carotenoid content. Fading of color appeared after 90 days due to storage temperature and oxygen content. On the other hand, the change can be happened for the error of sealing; exposure to light caused little deterioration in color. The flovour of all sample remained fresh up to 45 days during storage and the taste of the sample was pleasant and free from all types of objectionable matter. At 60 days of storage period, the flavour of sample $\mathrm{S}_{1}, \mathrm{~S}_{2}$ and $\mathrm{S}_{5}$ slightly changed. After 90 days later, sample $S_{1}$ and sample $S_{2}$ gained off flavour. The change took placefor the error of sealing.

Table 4. The effects of storage time on chemical compositions of mixed jams

\begin{tabular}{|c|c|c|c|c|c|c|c|}
\hline \multirow[t]{2}{*}{ Storage time } & \multirow[t]{2}{*}{ Parameters } & \multicolumn{5}{|c|}{ Sample } & \multirow[b]{2}{*}{$* \mathrm{~S}_{\mathrm{o}}$} \\
\hline & & $\mathrm{S}_{1}$ & $\mathrm{~S}_{2}$ & $\mathrm{~S}_{3}$ & $\mathrm{~S}_{4}$ & $\mathrm{~S}_{5}$ & \\
\hline \multirow{5}{*}{15 Days } & TSS (\%) & 67.00 & 67.00 & 67.00 & 67.00 & 67.00 & 67.00 \\
\hline & $\mathrm{pH}$ & 3.39 & 3.33 & 3.25 & 3.34 & 3.43 & 4.21 \\
\hline & Reducing sugar (\%) & 23.34 & 26.78 & 21.97 & 27.13 & 21.89 & 22.54 \\
\hline & Non-reducing sugar (\%) & 34.52 & 33.67 & 34.81 & 35.41 & 33.64 & 36.71 \\
\hline & Total sugar (\%) & 57.86 & 60.45 & 56.78 & 62.54 & 55.53 & 59.25 \\
\hline \multirow{5}{*}{30 Days } & TSS (\%) & 67.00 & 67.00 & 66.90 & 67.00 & 66.80 & 67.00 \\
\hline & $\mathrm{pH}$ & 3.38 & 3.31 & 3.25 & 3.34 & 3.43 & 4.21 \\
\hline & Reducing sugar (\%) & 23.34 & 26.78 & 21.97 & 27.13 & 21.88 & 22.54 \\
\hline & Non-reducing sugar (\%) & 34.52 & 33.67 & 34.81 & 35.41 & 33.64 & 36.71 \\
\hline & Total sugar (\%) & 57.86 & 60.45 & 56.78 & 62.54 & 55.52 & 59.25 \\
\hline \multirow{5}{*}{45 Days } & TSS (\%) & 66.90 & 67.00 & 66.90 & 67.00 & 66.70 & 67.00 \\
\hline & $\mathrm{pH}$ & 3.37 & 3.31 & 3.25 & 3.33 & 3.43 & 4.20 \\
\hline & Reducing sugar (\%) & 23.34 & 26.77 & 21.97 & 27.13 & 21.88 & 22.54 \\
\hline & Non-reducing sugar (\%) & 34.52 & 33.67 & 34.81 & 35.41 & 33.63 & 36.71 \\
\hline & Total sugar (\%) & 57.86 & 60.44 & 56.78 & 62.54 & 55.51 & 59.25 \\
\hline
\end{tabular}

$* \mathrm{~S}_{\mathrm{o}}=$ Control only pineapple; $\mathrm{S}_{1}=50 \%$ pineapple $+50 \%$ sweet gourd; $\mathrm{S}_{2}=40 \%$ pineapple $+60 \%$ sweet gourd; $\mathrm{S}_{3}=30 \%$ pineapple + $70 \%$ sweet gourd; $S_{4}=60 \%$ pineapple $+40 \%$ sweet gourd; $S_{5}=70 \%$ pineapple $+30 \%$ sweet gourd.

Table 4. The effects of storage time on chemical compositions of mixed jams (continued)

\begin{tabular}{|c|c|c|c|c|c|c|c|}
\hline \multirow[t]{2}{*}{ Storage Time } & \multirow[t]{2}{*}{ Parameters } & \multicolumn{6}{|c|}{ Sample } \\
\hline & & $\mathrm{S}_{1}$ & $\mathrm{~S}_{2}$ & $\mathrm{~S}_{3}$ & $\mathrm{~S}_{4}$ & $\mathrm{~S}_{5}$ & $* \mathrm{~S}_{\mathrm{o}}$ \\
\hline \multirow{5}{*}{60 Days } & TSS (\%) & 66.90 & 66.70 & 66.80 & 66.90 & 66.70 & 67.00 \\
\hline & $\mathrm{pH}$ & 3.37 & 3.30 & 3.24 & 3.33 & 3.42 & 4.20 \\
\hline & Reducing sugar (\%) & 23.33 & 26.76 & 21.96 & 27.12 & 21.88 & 22.54 \\
\hline & Non-reducing sugar (\%) & 34.51 & 33.67 & 34.80 & 35.41 & 33.63 & 36.71 \\
\hline & Total sugar (\%) & 57.83 & 60.43 & 56.76 & 62.53 & 55.50 & 59.25 \\
\hline \multirow{7}{*}{75 Days } & TSS (\%) & 66.70 & 66.70 & 66.70 & 66.60 & 66.70 & 66.80 \\
\hline & $\mathrm{pH}$ & 3.36 & 3.30 & 3.24 & 3.32 & 3.41 & 4.19 \\
\hline & Reducing sugar (\%) & 23.33 & 26.76 & 21.96 & 27.12 & 21.87 & 22.53 \\
\hline & Non-reducing sugar (\%) & 34.51 & 33.67 & 34.80 & 35.40 & 33.63 & 36.71 \\
\hline & Total sugar (\%) & 57.83 & 60.43 & 56.76 & 62.52 & 55.50 & 59.24 \\
\hline & TSS (\%) & 66.60 & 66.50 & 66.60 & 66.50 & 66.70 & 66.80 \\
\hline & $\mathrm{pH}$ & 3.36 & 3.30 & 3.23 & 3.32 & 3.41 & 4.19 \\
\hline \multirow{3}{*}{90 Days } & Reducing sugar (\%) & 23.31 & 26.76 & 21.96 & 27.12 & 21.87 & 22.53 \\
\hline & Non-reducing sugar (\%) & 34.51 & 33.67 & 34.80 & 35.40 & 33.63 & 36.70 \\
\hline & Total sugar (\%) & 57.82 & 60.43 & 56.76 & 62.52 & 55.50 & 59.23 \\
\hline
\end{tabular}

$* \mathrm{~S}_{\mathrm{o}}=$ Control only pineapple; $\mathrm{S}_{1}=50 \%$ pineapple $+50 \%$ sweet gourd; $\mathrm{S}_{2}=40 \%$ pineapple $+60 \%$ sweet gourd; $\mathrm{S}_{3}=30 \%$ pineapple + $70 \%$ sweet gourd; $\mathrm{S}_{4}=60 \%$ pineapple $+40 \%$ sweet gourd; $\mathrm{S}_{5}=70 \%$ pineapple $+30 \%$ sweet gourd. 
Table 5. Storage studies of mixed jam for color

\begin{tabular}{ccccccc}
\hline Storage days & \multicolumn{5}{c}{ Color } & \\
\cline { 2 - 6 } & $\mathrm{S}_{1}$ & $\mathrm{~S}_{2}$ & $\mathrm{~S}_{3}$ & $\mathrm{~S}_{4}$ & $\mathrm{~S}_{5}$ & $* \mathrm{~S}_{0}$ \\
\hline 15 Days & No change & No change & No change & No change & No change & No change \\
30 Days & No change & No change & No change & No change & No change & No change \\
45 Days & Slight change & Slight change & No change & No change & No change & No change \\
60 Days & Slight change & Slight change & Slight change & No change & Slight change & No change \\
75 Days & changed & Slight change & changed & No Change & Slight change & No change \\
90 Days & changed & changed & changed & Slight Change & Slight change & Slight change \\
\hline
\end{tabular}

$* \mathrm{~S}_{0}=$ Control only pineapple; $\mathrm{S}_{1}=50 \%$ pineapple $+50 \%$ sweet gourd; $\mathrm{S}_{2}=40 \%$ pineapple $+60 \%$ sweet gourd; $\mathrm{S}_{3}=30 \%$ pineapple + $70 \%$ sweet gourd; $S_{4}=60 \%$ pineapple $+40 \%$ sweet gourd; $S_{5}=70 \%$ pineapple $+30 \%$ sweet gourd.

Table 6. Results of storage studies of mixed jams for flavor

\begin{tabular}{|c|c|c|c|c|c|c|}
\hline \multirow[t]{2}{*}{ Storage days } & \multicolumn{6}{|c|}{ Flavor } \\
\hline & $\mathrm{S}_{1}$ & $\mathrm{~S}_{2}$ & $\mathrm{~S}_{3}$ & $\mathrm{~S}_{4}$ & $\mathrm{~S}_{5}$ & $* \mathrm{~S}_{\mathrm{o}}$ \\
\hline 15 Days & Good & Good & Good & Good & Good & Good \\
\hline 30 Days & Good & Good & Good & Good & Good & Good \\
\hline 45 Days & Good & Good & Good & Good & Good & Good \\
\hline 60 Days & Slight change & Slight change & Good & Good & Slight change & Good \\
\hline 75 Days & Slight change & Slight change & Slight change & Good & Slight change & Good \\
\hline 90 Days & Slight off flavor & Slight Off flavor & Slight change & Slight change & Slight changed & Slight change \\
\hline
\end{tabular}

$* \mathrm{~S}_{\mathrm{o}}=$ Control only pineapple; $\mathrm{S}_{1}=50 \%$ pineapple $+50 \%$ sweet gourd; $\mathrm{S}_{2}=40 \%$ pineapple $+60 \%$ sweet gourd; $\mathrm{S}_{3}=30 \%$ pineapple + $70 \%$ sweet gourd; $S_{4}=60 \%$ pineapple $+40 \%$ sweet gourd; $S_{5}=70 \%$ pineapple $+30 \%$ sweet gourd.

\section{Conclusion}

The color of the mixed jamsfrom sweet gourd and pineapple for all samples remained unchanged for 30 days. But at 45 days, the color of few samples changed to slight whitish. The color of sample $\mathrm{S}_{4}(60 \%$ pineapple $+40 \%$ sweet gourd) was unchanged for 75 days.The flovor of all samples remained fresh up to 45 days during storage time, and the taste of the samples was pleasant and free from all types of objectionable condition. This is a new area for the utilization of sweet gourd and pineapple. It may encourage more production of sweet gourd and pineapple, which will provide better nutrition to the people of Bangladesh.

\section{References}

AOAC. 2005: Official Methods of Analysis of Analytical Chemists, $18^{\text {th }}$ edition, Washington DC, USA.

BBS. 2012: Statistical Year Book of Bangladesh. Bangladesh Bureau of Statistics. Statistics Division, Ministry of planning. Govt. of the People's Republic of Bangladesh, 138-142.

Collins JL. 1968. Fruit Preservation and Uses, The Pineapples, World Crops Series. Leenard Hill. London. 229-239.

Ejiofor EJ and Owuno F. 2013. The physico-chemical and sensory properties of jackfruit (Artocarpus heterophyllus) jam. Int. J. Nutr. Food Science, 2(3): 149-152.
Gopalan S, Sastri BVR and Balasubramanian SC. 2001. Nutritive value of Indian Foods National Institute of Nutrition. Indian Council of Medical Research, Hyderabad, India. 204.

Kurt DA, Kruger RG and Maciel J. 2007. Composition of Pineapple juice. Journal of AOAC International, 5:280-282.

Pavlova L, Karakashova VL, Stamatovska V, Delchev N, Necinova L, Nakov G and Blazevska T. 2013. Storage impact on the quality of raspberry and peach jams. J Hyg. Eng. Design 5(1):25-28.

Rahman LMKA. 2007: Comparative studies of pineapple, papaya and ash gourd preserves and candies, MS thesis, Department of Food Technology and Rural Industries, BAU, Mymensingh.

Ranganna S 2003: Hand Book of Analysis of Quality Control for Fruit and Vegetable Products. Second edition, Tata McGraw Hill Publications Company Limited, New Delhi. 4-30.

Ranganna S, 2012: Handbook of Analysis and Quality Control for Fruit and Vegetable Products, 2nd Edition. Tata McGraw-Hill, New Delhi, India, 1112.

Sharfuddin AFM and Siddique MA 1985. "Shabjee Bigyan" (in Bengali). Mrs. Hasina Akhtar Beauty, Bangladesh Agricultural University, Mymensingh 8-9.

SAS. 1985. SAS users guide: Statistics, Version 5th edition. SAS Institute Inc., Cary, NC.

Singh R. 2002. Hand book of analysis of quality control for fruit and vegetables products. Second edition Tata Me Graw Hill pub. Co. Ltd., New Delhi.

Wikipedia 2012. http//:www.wikipedia.org/jackfruit retrieved September 24, 2012. 